\title{
Death-An Invincible Fact of Life: A Comparative Study Between Emily Dickinson and Louise Gluck
}

\author{
Tanzina Halim \\ Faculty of Languages \& Translation, King Khalid University, Abha, Saudi Arabia \\ Rizwana Wahid \\ Faculty of Languages \& Translation, King Khalid University, Abha, Saudi Arabia \\ Shanjida Halim \\ Faculty of Languages \& Translation, King Khalid University, Abha, Saudi Arabia
}

\begin{abstract}
The theme of death or mortality has been a recurrent theme in the works of many writers in literature. From time to time, various authors have discussed death in their works in different ways presenting it from different perspectives. It is a universal theme not confined to any specific group of people, country, or religion. This study focuses on the presentation of death in the poems of two female American poets Emily Dickinson (1830-1886) and Louise Gluck (1943 till today). Though both these female poets belong to two different centuries, the presentation of death in their works plays a dominant role. The presentation of death in the poems of Emily Dickinson makes the readers ponder over the concept of death from various angles. Similarly, the end of human life is one of the central themes of the poems of Louise Gluck. The discussion of death takes different shapes in the poetry of Louise Gluck. For this study, two pieces have been selected from the collection of Emily Dickinson and two pieces have been chosen from the collection of Louise Gluck. Hence, this present study aims to show the similarities and the differences between the concept and presentation of death in the works of these two leading female poets in the selected pieces.
\end{abstract}

Index Terms - comparison, concept, death, differences, poem

\section{INTRODUCTION}

The theme of death has inspired poets in all ages, and in literature, it is a recurrent theme. Addonizio and Laux (1997) have viewed death as a mystery since it has been imagined as nothingness, a journey to another state, or a prelude to the next life which has inspired poets to meditate profoundly. From time to time, studies have been conducted on the concept of death by various authors and poets. As death is inevitable, many poets such as John Donne, Dylan Thomas, T.S. Eliot, and W.B. Yeats have presented it in a grave tone. Among these poets, the obsession of John Donne with death is striking. Shin (2016) writes that Donne does not think of death as the end of life and surprisingly expresses the view that the way to defeat death is only through death. In a study by Daghamin (2017), it is stated that death is something that comes to us suddenly without any preparation or expectation, so it triggers our interest to a great extent. From time to time, it has been explored from different angles in literary pieces. It has always played an important role in literature. Death surrounds humans and their everyday life. It is a fact which can never be denied. Based on this, the researchers were interested in conducting a study between the two female American leading poets who have portrayed the theme of death in their pieces. In their poems, both poets have depicted the harsh and grim aspects of death. It has been shown as the ultimate destination of human life with nothing to glorify it. Therefore, this study explores how these two poets have presented death, showing the similarities in their presentation.

\section{A. Louise Gluck}

In literature, the theme of death has a very significant role in the works of many authors. Many poets and writers have presented the theme of death in various ways and from different perspectives. According to Rehman and Ahmed (2016), it has been viewed as one of the biggest mysteries for human beings. It has always drawn the interest of writers as it remains mysterious but inevitable. Death has been a prevalent theme in the poems of John Donne, Dylan Thomas, T.S. Eliot, and W.B. Yeats. Each of these poets has different approaches towards death. T.S. Eliot (1922) one of the major $20^{\text {th }}$ century poets, views death as a process to reach God and mourns the spiritual death of the modern people. On the other hand, W.B. Yeats (Ross, 2009) the modern Irish poet exalts death in his poems. Though these poets present the theme of death in their poems from various angles, they all agree that death is the final destination of human life. 
Louise Gluck is an American poet and essayist born on April 22, 1943, in New York City. She has won numerous major literary awards, including the Nobel Prize for Literature in 2020. She was praised for her poetic voice that contains austere beauty and marks individual existence as universal. The themes of her focus were trauma, desire, and nature expressing clearly sadness and isolation. By going through her verse, we are reminded of Emily Dickinson whose pain reinvented American poetry. In the opinion of Biespiel (1992), Louise Gluck is the heir to Dickinson's lyric empire of despair and sensation.

\section{B. Emily Dickinson}

Emily Elizabeth Dickinson, an American lyric poet, was born on December 10, 1830, Amherst, Massachusetts U.S. and died on May 15, 1886, Amherst, who lived in seclusion and had a unique brilliance of style and integrity of vision (Leiter, 2007).

As a poet with varying writing styles and extra-ordinary talent, she occupied a very prestigious position in the field of American literature. Her poems deal with various themes. She stands in sharp contrast to her great contemporaries like Whitman, Emerson, Hawthorne, and Thoreau (Aldalabeeh, 2018). She wrote poetry questioning the nature of death, immortality, trinity, religion, nature, love, God, etc. However, it is said that Dickinson is obsessed with death, which clearly reflects in her poems (Daghamin, 2017).

The theme of death is recurrent in the works of many poets, but Dickinson is renowned for her contribution to American literature for her unique presentation of Death (Strubel, 2014). According to Johnson (1955), "Emily Dickinson did so in hers to an unusual degree" (p. 203). Her knowledge of death is demonstrated in more than five hundred lyrics. "As she surveyed the broad universe and society itself, Emily perceived that death remained the one free agent, greater than nature, and second only to God" (Goyal, 1991). A thorough analysis of her poems show that there are four major categories: poems dealing with death and immortality, poems dealing with the physical aspects of death, poems that personify death, and elegiac poems. In a study conducted by Daghamin (2017), the theme of death in the poetry of Dickinson has attracted large critical attention. Death has preoccupied her life-long attention. In a study conducted by Liu (2016), Dickinson's poems are short but also meaningful. But the concept of death has found an important place in her poems. Whicher (1938) states that Dickinson "recurred to it more frequently than to any other" (p. 298).

\section{Thematic ANALysis OF THE POEMS}

The end of human life is one of the central themes of Gluck's poetry. Her rather dark and sinister writing style lends itself to the discussion of such a terminal fate. However, the discussion of death comes in different shapes. The poem, The Fear of Burial gives a bleak and depressing picture of death. The first stanza of the poem shows the tragedy of death when the poet writes

In the empty field, in the morning

The body waits to be claimed

The spirit sits beside it, on a small rock-

Nothing comes to give it form again. (The Garden, 1976)

Human beings do not adapt to changes easily. When they go through any changes, it takes time for them to adjust and accept the changes. After the body has experienced death, it has already made a permanent change, but the spirit has not. Rather than leaving quickly after death, the spirit stays with the body, sitting "beside it, on a small rock..." (Line no. 3, The Fear of Burial, 1976) as if it is unwilling to leave. It is still reluctant to leave the body alone as if it wants to come back to complete its unfulfilled desires.

In the second stanza, the poet asks the readers to reflect on the dead body's loneliness making the readers feel as if the body still has feelings. The readers even feel the loneliness of the body when they reflect upon the situation. It seems as if the spirit still desires to stay with what used to be its home when it takes the form of a shadow and wraps itself around the body. The spirit at this point in the poem knows that nothing will come "to give it form again..." (Line no. 4, The Fear of Burial) but still tries to resist the inevitable change it must make in its "long journey." It is said that humans have a natural tendency to feel like this when they undergo any permanent change and they still have the desire to hold on to familiar things. They do not think about what occurs between the moment of death and the burial of the body. The few people who have pondered on death deeply associate the dead body with feelings of loneliness and fear. There is no beauty in death. Once life ends, there is no turning back.

Similarly, the poem The Drowned Children (Descending Figure-1980) is a tragic poem about the death of a group of children drowned in a pond. The poetic persona narrates the story in a detached way. Her tone shows that there is a mood of acceptance in place of lamenting the loss. According to Daniel Morris (2006), the author "describes the gradual process of the dissolution and silencing of the anonymous children into an icy pond" (p. 4). The poet's attitude shows that there is no point in mourning or lamenting the loss. The poem also presents the indifferent attitude of the people towards the incident. The poem starts with

You see, they have no judgment.

So it's natural that they should drown. 
It creates the somber mood of the poem. The poem is not going to lament the loss. In the first stanza of the poem, the poet says the children were ignorant of what they were doing leading to their death. The poet says death is always egalitarian in nature and that is why she accepted those children without thinking much about their age. In the end, the poet says, the pond is responsible for their death as she has urged them to jump into it. It has engulfed the children in its 'manifold dark arms'.

Glück describes the tragic death of the children in the first stanza. Like a passive onlooker of things, the poet addresses readers to imagine how the incident appears to her. According to the poetic persona, death is natural. The children are destined to be drowned as they are ignorant and innocent. Their death is shocking at first hand, but it is also unavoidable. As those children ignored reality playfully, they faced such an unfortunate ending. In this stanza, the poet also presents how they died. After accidentally falling into the pond, the chilly winter has frozen their bodies, and later their bodies were found in that state.

In the second stanza, the poet talks about death. The poetic persona thinks those children would have died differently. Their death at such a young age is tragic. The poet scorns the attitude of death. According to the poet, the children faced this tragic ending because of their innocence. They failed to sense reality. They failed to predict the danger ahead of them, and it led to their demise. The last few lines of the stanza heighten the tragic mood of the poem. The cold reference to "their bodies" in the last line represents the transience of life. In the poem's last stanza, the poet visualizes their journey to the watery world in her poetic imagination. Their souls go back from where they came. The children are no more, and so there is nothing to grieve for. The poet wishes that their souls might rest in peace in heaven in the last three lines of the third stanza.

What are you waiting for

come home, come home, lost

in the waters, blue and permanent.

The pond is like a mother to them who calls to their children and they have no other choice but to respond to their mother's call. In the poem, the poet talks about death as a natural phenomenon and no overflowing emotions come from her heart regarding the death of those children. Hence, a close similarity can be noticed in the attitude of the poet's tone in the poem The Fear of Burial and The Drowned Children. In the poems, the theme of death comes in different shapes. She does not present death as something positive. There is no beauty in death and it is shown as something final and unavoidable. One can do nothing but accept death when it comes.

However, the poems of Emily Dickinson are no exception. She is well known for her repeated presentation of death in her poems. The theme of death also haunted other nineteenth-century poets such as Keats and Whitman, but none can be compared with Emily Dickinson's obsession in her reflection on the theme of death (Vendler, 2010). According to Anderson (1960), death and immortality were "the two most profound themes that challenged her poetic powers" (p. 284). Numerous studies have been done on the presentation of death in her poems. This section of the paper will discuss a couple of poems in which death plays an important role.

In a study by Daghamin (2017), it is stated that in some poems, Dickinson portrays death as a cruel personal enemy and as a brutal killer who attacks his victim without any permission or mercy. In the poem, A Clock Stopped, the poet shows a picture of how her subject suffers in the dying moments. Here, the victim suffers severe pain because of death. In the first stanza, she conveys the pain of losing dear ones and suggests the distance of the dead from the living (Vendler, 2010).

A clock stopped- not the mantel's

Geneva's farthest skill

Cant' put the puppet bowing

That just now dangled still.

It is about a clock suddenly coming to a stop. The poem deals with death and its deep philosophical and religious implications. Here, the dying person is compared to a moving clock- the conventional comparison of life to a clock. The last two lines, "Can't put the Puppet ... dangled still," suggest the sudden shift from movement to immobility. The puppet, which is still now moving, comes to a sudden stop and dangles still. The puppet image makes the readers reflect on the grim reality of death. The master craftsman has all the power to control it as it is moving and quick with life. But when it dangles lifeless and motionless, ironically, even his power and skill are ineffective. When human life is compared to a mechanical device like a clock and its sudden stopping, it clearly shows the helplessness of human beings in front of death. When death overtakes someone, no craft or skill can save that person.

The second stanza deals with the physical aspects of the body at the time of death. It is said that it focuses on the moment of death and the death throes and convulsions of the puppet. The body is compared to a trinket, a trifling ornament. The image of the clock and the figures remind people of the minutes and seconds of human lives gradually running out (Sarkar, 2020). The third stanza is concerned with the spiritual aspect of death. When human life reaches eternity, it cannot be revived. The grim comparison to a mechanical device emphasizes his meaninglessness' (Goyal, 1991). Despite the best efforts, human life cannot be restored.

The last stanza refers to the Decades of Arrogance of the Shopman, implying the shopman's arrogance who had guaranteed the life of the clock. However, when it fails, even the arrogance of the shopman has become meaningless. This reminds the readers of the lines in Robert Herrick's poem To Daffodils where he says that we all die just like the 
daffodil flowers. We grow, decay, and move towards death, never to be found again. Similarly, the human heart stops, too, one day. According to Goyal (1991), death baffles all human efforts to understand its meaning.

The poem I Felt a Funeral in My Brain (1896), another popular poem by Emily Dickinson, presents a manifestly disturbing portrayal of death. The verse shows the terrible struggle of the separation of the body from the soul. There is no hope of immortality. According to critics, 'the physical death symbolizes spiritual decease and perhaps a momentary insight into the nature of infinity' (Goyal, 1991). The emphasis on dying sensations and failing powers suggests death's dreadful isolation. On another level, the initial phase, 'in my Brain' hints that this physical death represents some terrible emotional pain or loss that brings an overwhelming sense of despair. Since the soul has lost its reason for living, the person has stopped existing. The poem's theme is not the funeral, real or imaginary, but it dwells upon losing one's grip on sanity. The theme is presented through the medium of the funeral image. According to Emily Dickinson, the funeral is the saddest experience in human life.

I felt a Funeral, in my Brain,

And Mourners to and fro

Kept treading - treading - till it seemed

That Sense was breaking through-

The scene opens with the mourners filing past the exposed body. The use of a funeral as a metaphor symbolically stands for the death of rationality. A funeral directly implies death and also a formal event where rules and procedures are counted. It is a process of moving from life to death which is similar to moving from sanity to madness. These mourners sit down and the service takes place, featuring first a drum beating and then - following the creaking lift of the lid of a box - a sound that reminds the speaker of a bell (suggesting the tolling of a funeral bell to announce someone's death). It is said that while reading, the speaker seems to collide with the entire world, until the speaker's mind is completely shut down and the speaker can no longer understand anything. The poem ends as the speaker describes what comes after this condition.

The speaker is part of the funeral. Monteiro (1959) concludes that the poem combines both triumph and failure, for man must return to reality after breaking through the barriers of sense into infinity.

\section{DISCUSSION}

It can be seen that there are striking similarities between the presentation of death by Emily Dickinson and Louise Gluck. Both Emily Dickinson and Louise Gluck see death as a natural phenomenon that brings pain, fear, agony, and suffering. In their poems, death has been depicted with all its harshness and gruesome aspects, leaving the readers to reflect on the cruelty of death.

Both the poems The Fear of Burial and I Felt a Funeral in my Brain describe the fear of being buried. It gives a bleak and depressing picture of death and there is nothing to glorify about death. It also shows the painful struggle of the spirit to leave behind the body. In the poem, The Fear of Burial, the body has experienced death and has undergone a permanent change, but the spirit of the deceased has not. Rather than leaving quickly after death, the spirit stays with the body, sitting "beside it, on a small rock..." (Line no. 3, The Fear of Burial) as if it is unwilling to leave. The spirit struggles to leave the dead body, and it lingers to stay back with the dead body and is reluctant to accept the changes that have taken place.

Similarly, the poem I Felt a Funeral in My Brain presents a disturbing portrayal of death. The poem shows how the body separates from the soul through a terrible struggle. There is no hope of immortality. The poem's theme is not the funeral, real or imaginary, and it gives a clear picture of the loss of sanity to madness. When a person loses his rational powers, he is no more than a dead person. Emily Dickinson finds the funeral to be the saddest experience in human life. The presentation of the theme creates a somber and gloomy atmosphere throughout. Both the poets show the gloomy and bleak picture of death, highlighting how the soul struggles to get separated from the body. Their presentation of death is remarkable and it shows its terrifying purpose.

A similarly depressing presentation is given in the poem The Drowned Children, where death engulfs a group of young children who may not have any idea about death. Society and the surrounding people are very indifferent to the incident. It is fated that the innocent children will die and their destination has pulled them towards the pond and led them to their untimely death. It shows the helplessness of the young, innocent victims in front of death.

A similar attitude towards death is found in the poem A Clock Stopped. In the poem, the poet presents the helplessness of human beings when death strikes. Through the imagery of the clock, she shows that though death is a shocking experience of life, it is unavoidable. When it comes, there is nothing a person can do to escape from its clutches. It is the ultimate endpoint that all humans have to reach. Both these poems show that once life ends, there is no turning back.

\section{CONCLUSION}

Death has remained and always will be an interesting and captivating topic in poetry and prose alike. It has always remained mysterious and will continue to remain mysterious. The theme of death plays an important role in our lives. No matter to which period the author belongs to, from time to time, various authors have presented the theme of death in 
multiple shapes and colors. The theme of death undoubtedly interests both authors and readers as it is a universal theme and an undeniable fact of life. It attracts the readers' attention due to its reality and power. The two poets Louise Gluck and Emily Dickinson, whose work have been discussed in this paper, are no exception. Their effortless contribution regarding the presentation of the theme of death is remarkable. They have presented a common theme in an uncommon and extraordinary way. They have portrayed death as bleakness, gloominess, and painful. There is no angle from which death can be glorified. The way they have shown the gruesome aspect of death makes the readers ponder over its power. Hence, this paper has tried to show the similarities between these two authors regarding their selected poems that deal with the theme of death.

\section{ACKNOWLEDGEMENTS}

The authors extend their appreciation to the Deanship of Scientific Research Deanship Research at King Khalid University for funding this work through a research program under grant number R. G. P. 1/146/42.

\section{REFERENCES}

[1] Addonizio, K. \& Laux, D. (1997). (Eds.) The poet's companion: A guide to the pleasure of writing poetry. London: W.W. Norton \& Company.

[2] Aldalabeeh, Y. A. N. (2018). Ordinary themes presented in an extra ordinary talent: An overview of Emily Dickinson's notable poems. International Journal of Applied Linguistics and Literature, 7(3), 60-66. http://dx.doi.org/10.7575/aiac.ijalel.v.7n.3p.60

[3] Anderson, C. R. (1960). Emily Dickinson's Poetry: Stairway of Surprise. New York: Holt, Rinehart, and Winston.

[4] Biespiel, D. (November 22, 1992). Poetry. The Washington Post. Retrieved October 8, 2021, from https://www.washingtonpost.com

[5] Daghamin, R. A. (2017). Reflection on death in the poetry of Emily Dickinson. InternationalJournal of Humanities and Social Science, 7(4), 148-154.

[6] Eliot, T. S. (1922). The Waste Land. The Oxford Companion to Twentieth-Century Literature in English.

[7] Gluck, L. (2021). Poems: 1962-2020. Penguin UK.

[8] Goyal, B. S. (1991). Emily Dickinson: Selected poems ( $7^{\text {th }}$ ed.). New Delhi: Educational Publishers.

[9] Johnson, T. H. (1955). Emily Dickinson: An interpretive biography. Harvard University Press.

[10] Leiter, S. (2007). Critical companion to Emily Dickinson: A literary reference to her life and work. New York: Facts on File Inc.

[11] Liu, Q. (2016). Death and immortality- An everlasting puzzle: A comparative analysis of Emily Dickinson's two poems. English Language and Literature Studies, 6(2), 172-176. https://doi.org/10.5539/ells.v6n2p172

[12] Monteiro, G. (1959). Emily Dickinson's Merchant God. Notes and Queries, 6, 455-456.

[13] Morris, D. (2006). Poetry of Louise Gluck: A thematic introduction. University of Missouri Press.

[14] Ross, D. A. (2009). Critical companion to William Butler Yeats: A literary reference to his life and work. New York: Facts on Life, Inc.

[15] Sarkar, S. (2020). Emily Dickinson as a poet of death. All About English Literature. Retrieved October 9, 2021, from https://www.engliterature.com/2020/10/emily-dickinson-as-poet-of-death-or.html

[16] Shin, H. (2016). Death and afterlife in John Donne's poetry. Hankuk University of Foreign Studies Literature Studies 64, 133154. http://dx.doi.org/10.22344/fls.2016.64.133

[17] Strubel, A. R. (2014). We tell ourselves stories. In Hakola, O. and Kivisto, S. (Eds.), Death in literature (pp. 3-14). Cambridge Scholars Publishing.

[18] Rehman, H. J. \& Ahmed, M. (2016). Theme of death with special reference to selected English and Arabic poets. Al-Azhaar, 2 (2), 34-49. https://doi.org/10.12816/0037986

[19] Vendler, H. (2010). Dickinson: Selected poems and commentaries. London: The Belknap Press of Harvard University Press.

[20] Whicher, G. F. (1938). This was a poet: A critical biography of Emily Dickinson. New York: Charles Scribner's Sons.

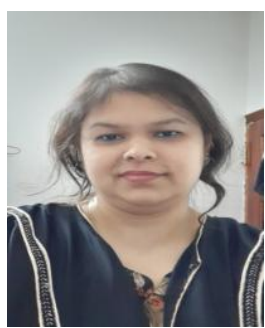

Tanzina Halim is working as a Lecturer at the Dept. of English, Faculty of Languages \& Translation, King Khalid University, Saudi Arabia. She has an M.A. in English Literature \& Language. She is TEFL certified, has Diploma in TESOL and Diploma in Teacher Training. She is interested in language teaching, creative writing and has publications in some International Journals.

Rizwana Wahid is an assistant professor working at English Language Centre, Faculty of Languages \& Translation, King Khalid University. ORCID Id: 0000-0003-3845-6030 


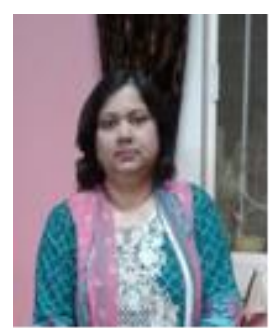

Shanjida Halim is working as a Lecturer at the Dept. of English, Faculty of Languages \& Translation, King Khalid University, Saudi Arabia. She has an M.A. in English Literature and an M.A. in English Language Teaching (ELT). She is TEFL certified, has Diploma in TESOL and Diploma in Teacher Training. She is interested in language teaching, creative writing and has publications in some International Journals. 